\title{
Patología
}

www.elsevier.es/patologia

BRIEF REPORT

\section{Exuberant complex metaplastic carcinoma of the breast with SOX2 expression: Cove ring the full spectrum of ductal neoplasia of the breast}

\section{Amaia Sagasta ${ }^{a}$, Adela Saco $^{a}$, Leonardo Rodríguez-Carunchio ${ }^{a}$, Ramón Rull $^{\mathrm{b}}$, Ana Ruiz $^{\mathrm{c}}$, Ana Carrió ${ }^{\mathrm{a}}$, Reynaldo Falcón-Escobedo ${ }^{\mathrm{d}}$, Pedro Luís Fernández ${ }^{\mathrm{a}, \mathrm{e}, *}$}

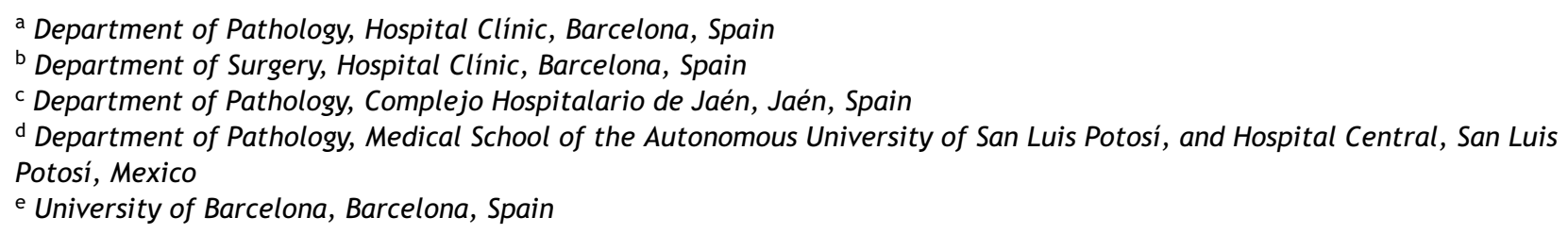

Received 25 August 2014; accepted 2 October 2014

Available online 21 November 2014

\section{KEYWORDS \\ Breast cancer; \\ Metaplastic \\ carcinoma; \\ SOX2}

\begin{abstract}
We report a unusual case of a 45-year-old woman with a massive metaplastic carcinoma of the breast with a complex admixture of components including giant pleomorphic cells, sarcomatoid areas, cysts with undifferentiated stratified epithelium, squamous carcinoma foci, high grade comedo-type ductal carcinoma in situ, high grade invasive carcinoma not otherwise specified (NOS) and foci with osseous differentiation. An extensive immunohistochemical panel showed expression of both epithelial and mesenchymal markers. The self-renewal marker SOX2 was expressed in different cell types, which was interpreted as a sign of the pluripotency what can in turn explain the diversity of histologic lineages present in this tumour.
\end{abstract} (c) 2014 SEAP y SEC. Published by Elsevier España, S.L.U. All rights reserved.
PALABRAS CLAVE

Cancer de mama;

Carcinoma

metaplásico;

SOX2

\begin{abstract}
Carcinoma metaplásico de la mama con expresión de SOX2 y presentación clínica exuberante: recorriendo el amplio espectro de la neoplasia ductal de la mama
\end{abstract}

Resumen Presentamos el caso de una mujer de 45 años con un carcinoma metaplásico de presentación clínica exuberante, que mostraba una combinación compleja de diversos componentes, incluyendo células gigantes pleomórficas, áreas sarcomatoides, quistes con epitelio

\footnotetext{
* Corresponding author.

E-mail address: plfernan@clinic.ub.es (P.L. Fernández).
} 
escamoso indiferenciado, focos de carcinoma escamoso, carcinoma ductal in situ de tipo comedo, carcinoma infiltrante de tipo usual y focos de diferenciación ósea. El amplio panel inmunohistoquímico mostraba expresión de marcadores tanto epiteliales como mesenquimales. El marcador de autorenovación SOX2 se expresaba en diferentes tipos celulares, lo cual fue interpretado como un signo de pluripotencialidad y podría explicar la diversidad de tipos histológicos presentes en este tumour.

(c) 2014 SEAP y SEC. Publicado por Elsevier España, S.L.U. Todos los derechos reservados.

\section{Introduction}

According to the WHO classification, the term "metaplastic carcinoma" includes a group of neoplasms characterized by differentiation of the neoplastic epithelium into squamous cells and/or mesenchymal-looking elements. ${ }^{1}$ This is a broad designation and therefore distinct entities with heterogeneous morphology are encompassed.

We present a clinically exuberant metaplastic breast carcinoma with complex histology and immunophenotype with various types of epithelial components admixed with high grade mesenchymal elements including pleomorphic giant cells and osteosarcoma. We discuss the possible relationship between these various components and highlight the pluripotentiality of some of its tumour cells which express the stem cell marker SOX2.

\section{Case report}

A 45-year-old woman presented in the emergency room with an excrescent mass in her right breast which occupied the whole right hemithorax. The breast was unrecognizable on initial examination. The tumour mass was ulcerated with seropurulent secretion (Fig. 1a). The patient had marked signs of emaciation but reported a clinical course of only 2 weeks, which was considered unlikely due to the size of the tumour and her history of psychological impairment.

After hospital admission a core biopsy was performed and a diagnosis of a high grade neoplasia of predominantly mesenchymal phenotype was made with the possibility of a metaplastic carcinoma due to the expression of both vimentin and cytokeratins in tumour cells. Radical mastectomy was performed and gross examination showed a tumour weighing $1250 \mathrm{~g}$ and measuring $22 \times 17 \mathrm{~cm}$, with mushroom-like growth. The cut surface showed a very heterogeneous mass with cystic spaces, necrosis, haemorrhagic areas and surface ulceration, with extensive infiltration of the soft tissue but without involvement of the pectoral muscle comprising the surgical margin (Fig. 1b). The nipple was not immediately obvious but was identified close to the ulcer margin. Axillary node evaluation could not be performed because of the refusal of the patient to undergo any other surgical procedure. The specimen was fixed in $10 \%$ buffered formalin. Sections of $3-\mu \mathrm{m}$ thickness were cut from paraffin-embedded material and stained with haematoxylin and eosin. A wide panel of immunohistochemical staining was performed (Table 1). The immunohistochemical reactions were developed with the Envision system (Autostainer 48, DAKO, Denmark). The source and dilutions of the primary antibodies are also shown in Table 1. FISH study for theTP53 gene was performed with the LSI TP53 (17p13.1) and centromeric CEP17 probes (Abbot Molecular, Des Plaines, IL). Briefly, paraffin sections were deparaffinized, air dried, and pretreated in a pressure cooker. The slides were subsequently digested with proteinase $\mathrm{K}$ for $15 \mathrm{~min}$ at $37^{\circ} \mathrm{C}$ and the probe applied and co-denatured with the target DNA at $80^{\circ} \mathrm{C}$ for $5 \mathrm{~min}$. The slides were then hybridized at $37^{\circ} \mathrm{C}$ overnight in a Thermobrite apparatus (Abbot Molecular). After stringent washing 10\% DAPI (Abbott Molecular) was used for counterstaining. Hybridization and digital image acquisition, processing, and evaluation were performed using the ISIS digital image system V5.0 (Metasystem, Altlussheim, Germany). A similar procedure was carried out with probes for chromosomes 8, 18 and X (Abbot Molecular, Des Plaines, IL).

Histologically, the tumour showed an approximately equal amount of mesenchymal spindle cell component and carcinoma. The latter included stratified epithelium covering cysts (Fig. 1c) morphologically resembling squamous cells in some areas and transitional or undifferentiated cells in others. Other locations showed poorly differentiated squamous foci and well-differentiated squamous carcinoma scattered throughout the tumour (Fig. 1d) and sparse foci of high grade comedo-type ductal carcinoma in situ (DCIS) with adjacent high grade invasive carcinoma NOS (Fig. 1e). The tumour also showed numerous giant pleomorphic cells (Fig. 1f) and sarcomatoid areas with a predominantly spindle cell component corresponding to high grade sarcoma, areas resembling malignant fibrous histiocytoma and areas with osseous differentiation (Fig. 1g). The giant pleomorphic cells frequently showed bizarre nuclei, multiple prominent nucleoli, multinucleation and "cannibalism" and were often located beneath the epithelium of the cysts (Fig. 1h). The mitotic rate was very high in all areas (more than 30 mitotic figures per $10 \mathrm{HPFs}$ in sarcomatous areas). Atypical mitoses were frequently seen. Lymphovascular invasion was present in peripheral areas. The surgical margins were negative.

A summary of the immunohistochemical results is recorded in Table 1 . Briefly, cytokeratins were positive in the different epithelial components, focally positive in giant pleomorphic cells (Fig. 2a) and negative in spindle cell areas 

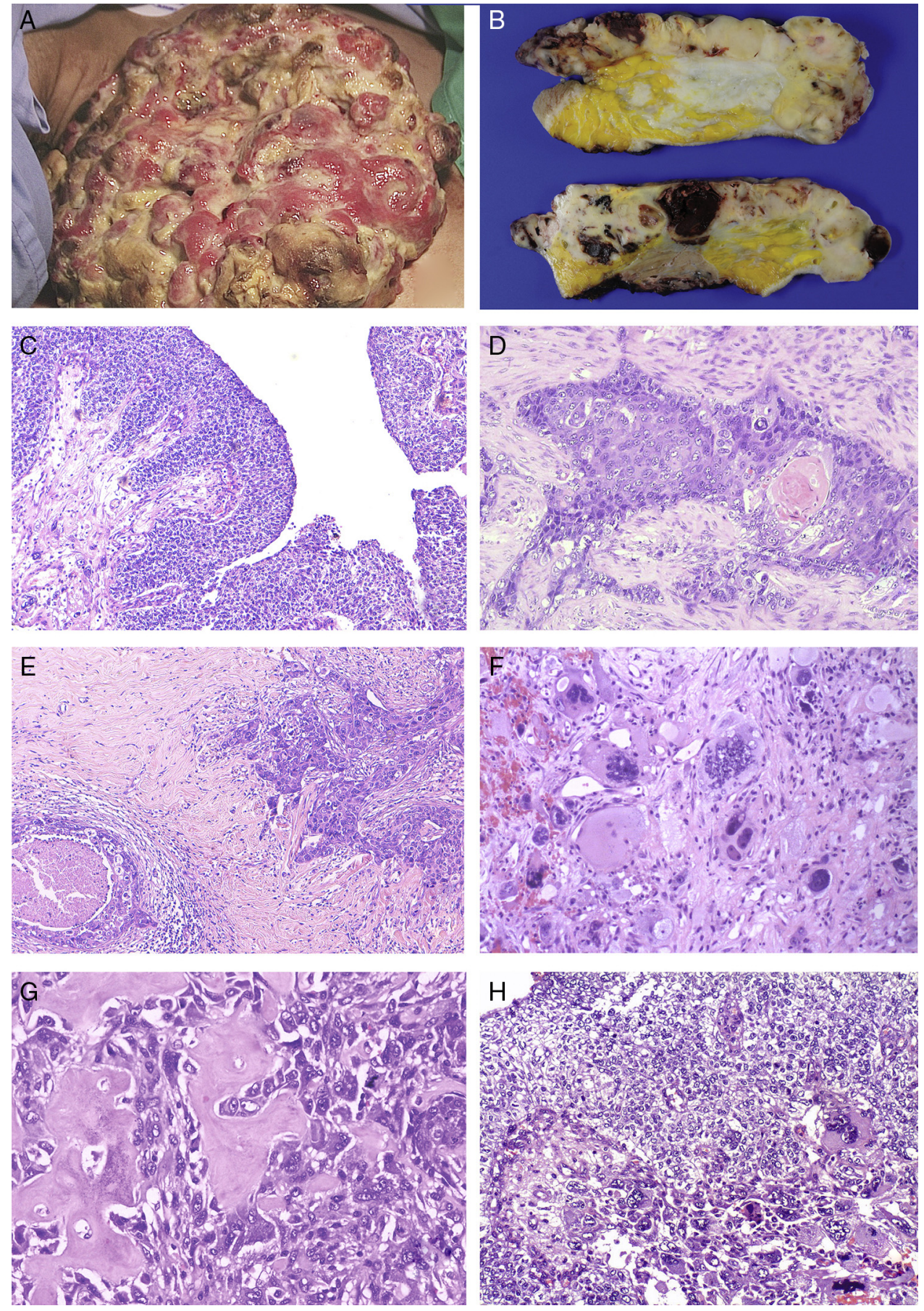

Figure 1 (a) In situ macroscopy of the tumour involving most of right thorax; (b) macroscopic section showing ulceration and haemorrhagic and cystic areas; (c) poorly differentiated stratified epithelium of a neoplàstic cyst, H\&E $\times 100$; (d) area of well differentiated squamous carcinoma, $\mathrm{H \& E} \times 20$; (e) DCIS next to high grade invasive carcinoma NOS, H\&E $\times 100$; (f) area with predominant pleomorphic giant cells, H\&E $\times 200(\mathrm{~g})$; focus of osteosarcoma, H\&E $\times 400(\mathrm{~h})$; morphological transition between undifferentiated carcinoma and pleomorphic giant cells, H\&E $\times 100$.

(Fig. 2b). Vimentin was strongly and diffusely positive in all the giant pleomorphic cells (Fig. 2c) and sarcomatoid areas (Fig. 2d) and negative in the invasive and DCIS components, although focal but strong positivity was also found in the epithelium of the cysts (not shown). p53 was diffusely positive in all the morphological components of the tumour, with $100 \%$ positivity in invasive and DCIS cells (Fig. 2e) and $70 \%$ positivity in pleomorphic giant cells (Fig. 2f). p63 was diffusely positive in DCIS myoepithelial cells and in the basal layer of epithelium of the cysts. It was also expressed in plemorphic giant cells (60\% positivity) (Fig. $2 \mathrm{~g}$ ), with focal positivity in invasive carcinoma NOS and spindle cell areas. In contrast, oestrogen and progesterone receptors were negative in all the components whereas c-erbB2 
Table 1 Tumour components/immunohistochemical expression.

\begin{tabular}{|c|c|c|c|c|c|c|c|}
\hline & $\mathrm{T} / \mathrm{S}^{\mathrm{a}}$ & Dilution & $\mathrm{DCIS}^{\mathrm{b}}$ & IC NOSC & $\begin{array}{l}\text { Cyst } \\
\text { epithelium }\end{array}$ & $\begin{array}{l}\text { Pleomorphic } \\
\text { giant cells }\end{array}$ & $\begin{array}{l}\text { Spindle cell } \\
\text { area }\end{array}$ \\
\hline CK AE1/AE3 & $\mathrm{M}^{\mathrm{d}} /$ Dako & RTU & $\mathrm{ND}^{f}$ & + & $+++D^{g}$ & $+\mathrm{F}^{\mathrm{h}}$ & - \\
\hline CAM 5.2 & & & + & + & $+\mathrm{F}$ & $+\mathrm{F}$ & - \\
\hline CK $34 \beta E 12$ & M/Dako & RTU & $+\mathrm{F}$ & $+D$ & $+++\mathrm{F}$ & $+I C^{i}$ & - \\
\hline EMA & & & ND & ND & $++D$ & $+\mathrm{F}$ & - \\
\hline VIMENTIN & M/Dako & RTU & - & - & $+++\mathrm{F}$ & $+++D$ & $+++D$ \\
\hline CD 68KP1 & M/Dako & RTU & - & - & $-D$ & $+D$ & - \\
\hline p63 & M/Roche & RTU & $\begin{array}{l}+\mathrm{D} \\
\text { myoepith.c. }{ }^{\mathrm{j}}\end{array}$ & $\begin{array}{l}+\mathrm{D} \text { squam. } \\
\text { c. }{ }^{k}\end{array}$ & +D basal c. & $+D$ & $+\mathrm{F}$ \\
\hline p53 & M/Dako & RTU & $+D$ & $+D$ & $+D$ & $+D$ & $+D$ \\
\hline Ki67 & M/Dako & RTU & $+40 \%$ & $+40 \%$ & +basal c.' & $+50 \%$ & $+30 \%$ \\
\hline ER & M/Dako & RTU & - & - & - & - & - \\
\hline PR & M/Dako & RTU & - & - & - & - & - \\
\hline HER2 & $\mathrm{P}^{\mathrm{m}} / \mathrm{DK}$ & $1 / 700$ & $1+$ & $1+$ & 0 & 0 & 0 \\
\hline SOX2 & $\mathrm{P}$ & $1 / 30$ & $+\mathrm{IC}$ & - & $+\mathrm{F}$ & $+70 \%$ & $+70 \%$ \\
\hline $\begin{array}{l}\text { a } T / S: \text { type/ } \\
\text { b DCIS: duct } \\
\text { c IC NOS: in } \\
\text { d M: monocl } \\
\text { e RTU: read } \\
\text { f ND: not do } \\
\text { g D: diffuse, } \\
\text { h F: focal, r } \\
\text { i IC: isolate } \\
\text { j myoepith. } \\
\text { k squam. C: } \\
\text { I basal C.: b } \\
\text { m P: polyclo }\end{array}$ & $\begin{array}{l}\text { e. } \\
\text { cinoma in s } \\
\text { se. } \\
\text { esents }>50 \% \\
\text { ents }<50 \%+ \\
\text { s, represen } \\
\text { yoephitelial } \\
\text { nous compo } \\
\text { sells. }\end{array}$ & $\begin{array}{l}\text { therwise } \\
\text { s. } \\
\text { + cells. }\end{array}$ & ed. & & & & \\
\hline
\end{tabular}

protein expression was $1+$ in invasive and DCIS and negative in the rest. $\mathrm{Ki} 67$ showed high proliferation of all components, being positive in more than $50 \%$ of the giant pleomorphic cells, the spindle cell component and invasive ductal carcinoma. Given the variegated appearance of the tumour and the conceptual possibility that the tumour arose from very undifferentiated and multipotential cells of the mammary cell linage ${ }^{2}$ the self-renewal marker SOX2 was also analyzed. SOX2 was negative in invasive carcinoma NOS and in DCIS with the exception of only one positive cell in this component. In contrast, neoplastic cyst epithelium was focally positive and pleomorphic giant cells and spindle cell areas showed diffuse positivity (Fig. 2h) which coincided with p63 expression in some bizarre cells. Additionally, FISH for TP53 showed multiple copies of the gene as centromer chromosome 17 in the giant pleomorphic cells, most likely caused by polyploidy given that analysis of chromosomes 8 and $X$ - also showed polysomy.

The tumour was finally diagnosed as metaplastic carcinoma of the breast with a descriptive comment which included all the phenotypical components.

\section{Discussion}

This rare case has an interestingly exuberant clinical presentation and complex histological phenotype. Heterologous elements are unusual in breast cancers and when present may account for a greater or lesser component of the tumour. In this case, the main component of the neoplasia was high grade sarcoma (50\%) with pleomorphic elements, with the remaining components being predominantly squamous carcinoma and undifferentiated carcinoma covering cysts and accompanied by rare in situ and invasive carcinoma NOS.

Pleomorphic carcinoma has several features in common with the present case. First described by Silver \& Tavassoli ${ }^{3}$ it is defined by a pleomorphic cell population (>six-fold variation in nuclear size) comprising $\geq 50 \%$ of the tumour. It is considered that a metaplastic component can also be present in this type of tumour but without exceeding $25 \% .{ }^{4}$ Although a highly pleomorphic cell population reaching the established criteria was prominent in our case, the metaplastic component was clearly above $25 \%$ and included extensive areas of high grade sarcoma, and, therefore, is better considered academically as a metaplastic carcinoma with pleomorphic features rather than a pure pleomorphic carcinoma. Another unusual feature of our case was the presence of focal osteosarcoma.

It remains controversial whether the carcinomatous and sarcomatous components of metaplastic carcinoma of the breast both arose separately from cancer stem cells or following the transformation of the carcinomatous component into a sarcomatous phenotype through epithelial to mesenchymal transition or dedifferentiation. ${ }^{5-7}$ It has nevertheless also been suggested that the distinct components in metaplastic carcinomas are clonally related in the vast majority of cases. ${ }^{8,9}$ Although definitive conclusions 

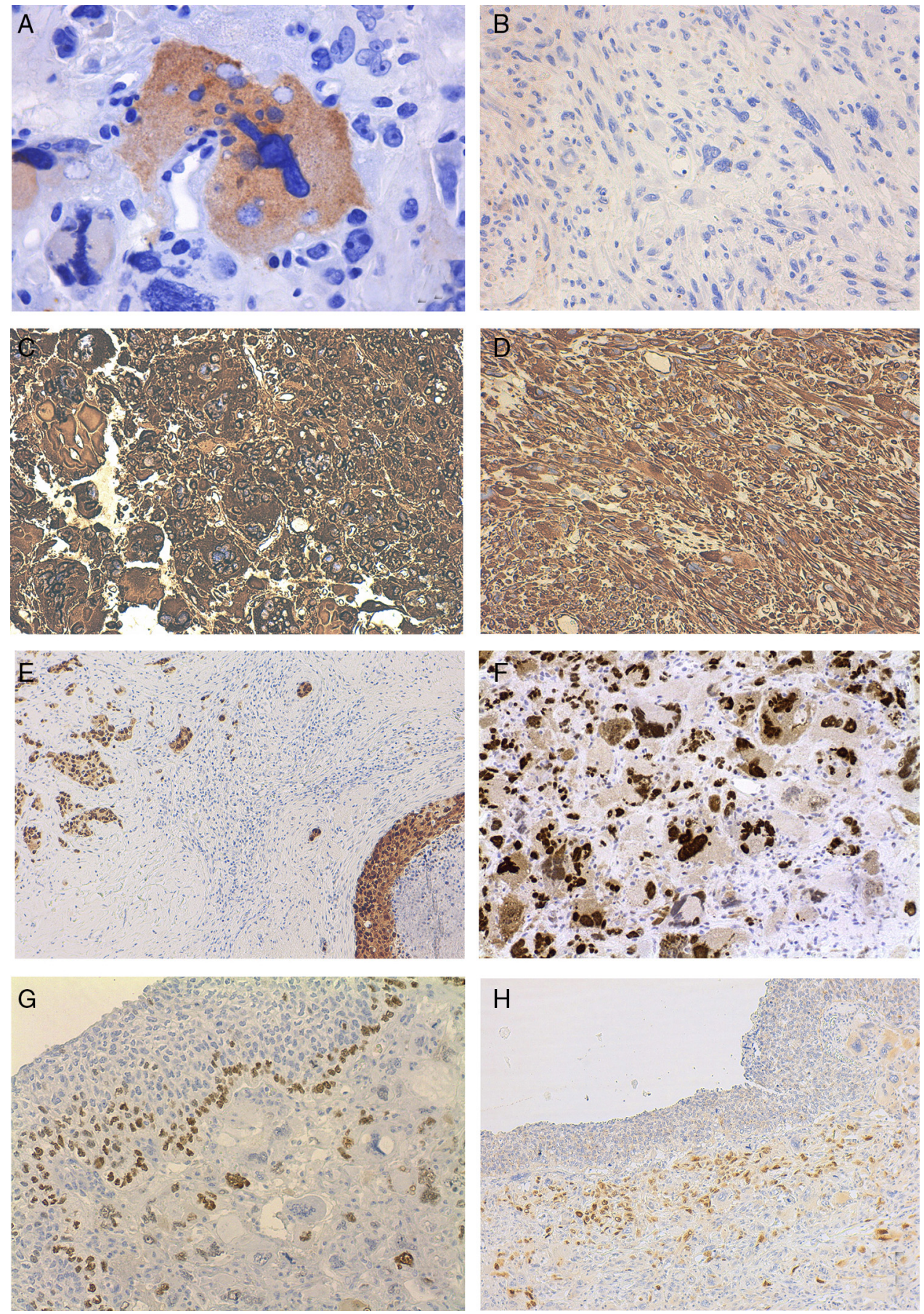

Figure 2 (a) Expression of EMA in pleomorphic giant cells, DAB $\times 600$; (b) pure spindle cell areas were negative for cytokeratins $A E 1 / A E 3, D A B \times 200$; (c) diffuse vimentin expression in giant cells component, $D A B \times 200$ (d) and in spindle cell areas, DAB $\times 200 ;(e)$ P53 was overexpressed in DCIS and IDC NOS, DAB $\times 100$; ( f) pleomorphic giant cells were mostly strongly positive for P53, DAB $\times 100$; (g) P63 was expressed by some giant pleomorphic cells and the basal layer of cyst epithelium, DAB $\times 200$; (h) SOX2 expression was observed in giant pleomorphic cells underlying the epithelial layer of the cysts, $D A B \times 100$.

cannot be drawn from our case, complex phenotypical traits of this carcinoma confirm the extreme plasticity that breast cancer cells can achieve in which cell pluripotency must be involved. This capacity is traditionally assigned to cells with stemness features ${ }^{2}$ and although conclusive detection of cancer cells with these characteristics would require a wide panel of other immunophenotypical markers such as CD 44 and CD 24 and aldehyde dehydrogenase (ALDH) activity, ${ }^{10}$ the expression of SOX2 in undifferentiated cyst epithelium and the sarcomatous component of our case suggest that cells with such pluripotency are abundant and allow somewhat divergent lineages reaching differentiated endpoints such as squamous and osteosarcoma cell populations. Although we cannot refute the possibility that SOX2 expression may merely represent a squamous trait (it is also expressed in epithelium of the skin), its coincidence in 
pleomorphic cells with p63, also involved in the maintenance of epithelial stem cells in the breast, ${ }^{11}$ suggests a relationship with a pluripotent phenotype. Thus we propose that this case is rich in cancer stem cells, or, at least, pluripotent cells and epithelial-to-mesenchymal features, and that the histologically distinct components of this tumour are probably clonally related. Indeed, most tumour cells overexpressed P53, including those in the DCIS component, suggesting an early event inherited by the different lineages of this complex neoplasm apparently caused by polysomy, although other abnormalities such as mutations cannot be ruled out without further analyses.

In the present case, the giant pleomorphic cells showed an epithelial inmunophenotype in some areas and a mesenchymal immunophenotype in others, with some cells showing both and not being morphologically distinguishable. Moreover, they seemed to originate from undifferentiated carcinoma (Fig. $1 \mathrm{~h}$ ) or the epithelium of the cysts (Fig. 2h) which, together with their sometimes combined epithelialmesenchymal phenotype suggest that the SOX2 positive pleomorphic cells may represent a population of elements with great plasticity and pluripotency from which more differentiated elements could originate. However, the possibility that these pleomorphic elements represent terminal highly aberrant and genetically adrift cells can not be excluded.

From the clinical point of view, it is very surprising that a patient with a tumour with such an aggressive appearance (large size, diffuse P53 expression, high histological grade and proliferation) and without any other adjuvant treatment was disease-free 4 months after the diagnosis, although she was lost for clinical follow-up thereafter.

In summary, we have presented a clinically and morphologically striking metaplastic carcinoma of the breast which illustrates the great plasticity of mammary epithelium and the diagnostic challenges and histogenetic uncertainties associated with this type of neoplasm.

\section{Funding}

Financial support was provided by grant from the Ministerio de Economía y Competitividad SAF2012-40017-C02-02.

\section{Conflict of interest}

The authors declare that there are no conflicts of interest.

\section{Ethical disclosures}

Protection of human and animal subjects. The authors declare that no experiments were performed on humans or animals for this study.
Confidentiality of data. The authors declare that they have followed the protocols of their work centre on the publication of patient data

Right to privacy and informed consent. The authors declare that no patient data appear in this article.

\section{Acknowledgements}

We thank Mrs. Ingrid Victoria for technical assistance and Mr. Xabier Sagasta for imaging assistance.

\section{References}

1. Reis-Filho JS, Lakhani SR, Gobbi H, Sneige N. Metaplastic carcinoma. In: Lakhani SR, Ellis IO, Schnitt SJ, Hoon Tan P, van de Vijver, editors. WHO Classification of Tumours of the Breast Lyon: International Agency for Research on Cancer; 2012. p. 48-52.

2. Visvader JE, Lindeman GJ. Cancer stem cells: current status and evolving complexities. Cell Stem Cell. 2012;10: 717-28.

3. Silver SA, Tavassoli FA. Pleomorphic carcinoma of the breast: clinicopathological analysis of 26 cases of an unusual high-grade phenotype of ductal carcinoma. Histopathology. 2000;36:505-14.

4. Nguyen CV, Falcon-Escobedo R, Hunt KK, Nayeemuddin KM, Lester TR, Harrell RK, et al. Pleomorphic ductal carcinoma of the breast: predictors of decreased overall survival. Am J Surg Pathol. 2010;34:486-93.

5. Cooper CL, Karim RZ, Selinger C, Carmalt H, Lee CS, O'Toole SA. Molecular alterations in metaplastic breast carcinoma. J Clin Pathol. 2013;66:522-8.

6. Teixeira MR, Qvist H, Bohler PJ, Pandis N, Heim S. Cytogenetic analysis shows that carcinosarcomas of the breast are of monoclonal origin. Genes Chromosomes Cancer. 1998;22: 145-51.

7. van Deurzen $\mathrm{CH}$, Lee $\mathrm{AH}$, Gill MS, Menke-Pluijmers $M B$, Jager A, Ellis IO, et al. Metaplastic breast carcinoma: tumour histogenesis or dedifferentiation? J Pathol. 2011;224: $434-7$.

8. Geyer FC, Weigelt B, Natrajan R, Lambros MB, de Biase D, Vatcheva R, et al. Molecular analysis reveals a genetic basis for the phenotypic diversity of metaplastic breast carcinomas. J Pathol. 2010;22:562-73.

9. Thompson L, Chang B, Barsky SH. Monoclonal origins of malignant mixed tumors (carcinosarcomas): evidence for a divergent histogenesis. Am J Surg Pathol. 1996;20: 277-85.

10. Owens TW, Naylor MJ. Breast cancer stem cells. Front Physiol. 2013;4:225.

11. Yallowitz AR, Alexandrova EM, Talos F, Xu S, Marchenko ND, Moll UM. p63 is a prosurvival factor in the adult mammary gland during post-lactational involution, affecting $\mathrm{PI}$ MECs and ErbB2 tumorigenesis. Cell Death Differ. 2014;21: 645-54. 